MIRIAM LANG'

\title{
Social Justice and Civilisational Crisis: Clues for Rethinking Poverty Eradication Based on Sustainability and Interculturality ${ }^{2}$
}

The most severe migratory crisis in history and profound environmental crisis we are living through are only two dimensions of a wider civilisational crisis. This not only causes us to question the idea of an imitative development, which supposedly traces the path along which the South must 'progress' following industrialised nations, but it entails problematising the hegemonic notions of what a good life is and what human needs are, as well as questioning the current international division between work and Nature. In this article, I wish to analyse the challenges that today's civilisational crisis poses to those concerned with social justice and the plural left, especially those concerned with the desire to build equality and reduce poverty. I discuss the legacy we were left with in regard to 20th century socialism, which for a long time occupied a central space in debates relating to social transformation. I also examine recent Latin American progressivisms, in particular the Ecuadorian experience, analysing the effects of what has been described as its greatest success, poverty reduction, in light of the civilisational crisis. Finally, in a dialogue with Laudato Si, I outline several ideas on how to integrate social justice with environmental justice and rethink such central concepts as wealth and poverty, as

\footnotetext{
${ }^{1}$ MIRIAM LANG is Profesora del Área de Estudios Sociales y Globales de la Universidad Andina Simon Bolivar, Ecuador.

2 This article was originally published in http://www.alternautas.net/blog/2019/11/16/socialjustice-and-civilisational-crisis-clues-for-rethinking-poverty-eradication-based-on-sustainabilityand-interculturality
} 


\section{Social Justice and Civilisational Crisis | 30}

well as redistribution and inclusion in the face of the challenges that the 21 st century poses.

\section{Civilisational Crisis}

According the information provided in June 2017 by the UN High Commissioner for Refugees (UNHCR) in Geneva, more than 65.6 million people have been forcefully displaced at the time of writing (UNHCR, 2017). A sad historic record. Only half of them come from war zones such as Syria, Sudan or Afghanistan. Millions have been expelled due to the externalities of a way of life that seems normal to some and desirable to others. Never before has the destructive appropriation of the material conditions for the reproduction of life been as intense and accelerated as today. Where before, one hydroelectric dam was built, displacing a community, today dozens are constructed, hundreds of dams atop the same river to satiate the infinite appetite for energy produced by the economic growth paradigm and the corresponding capitalist/modern/Western way of life. Similarly, mining enterprises, non-conventional hydrocarbon exploitations, and the hoarding of lands for the production of (non-food!) agricultural commodities are all multiplying. As noted by Pope Francis, "it is tragic the rise in migrants fleeing misery made worse by environmental degradation, that they are not recognised as refugees in international conventions and carry the weight of their abandoned lives without any legal protection" (Francisco 2015, 23). ${ }^{3}$ In effect, the majority of campesinos that are forced to leave their lands and seek their survival in the city are not counted as displaced but are counted in the more innocuous statistic of rural-urban migration. However, the material conditions of their previous way of life have been destroyed.

Usually, the justification is that there is no alternative to modernisation, to progress or to development and that this irresistible avalanche of megaprojects is necessary to fight poverty and include the excluded. This justification labels as miserable, poor and therefore eradicable those ways of life that live with little, that practice a true

\footnotetext{
3 Translator's note: where possible, text has been taken from the English versions of Praise be to You. Nevertheless, page numbers correspond to the original Spanish citations.
} 
sustainability within their territories, that consider themselves a part of nature, and that extol virtues other than profit, efficiency and the accumulation of material wealth.

The dominant way of life that is founded in the idea of unlimited economic growth, because it takes place on the finite sphere called "Planet Earth", has led us to a multidimensional crisis that threatens life itself on this planet and that thinkers from different disciplines and regions describe as not only multidimensional but civilisational (Echeverría 2008, Lander 2009, Lang 2011, Ornelas 2013). Decades ago the natural sciences called our attention to the biophysical limits of the planet, from those focused on the scarcity of resources (Meadows and Meados 1972) to those who more recently have established the carrying capacity of different ecosystems, such as Rockström et al (2009). Voices critical of globalisation speak of a structural, longterm world-system crisis that leads to deep global asymmetries, a growing social polarisation, and runaway inequality, as well as accelerated environmental destruction that manifests itself, for example, through global warming (Gills 2010). Furthermore, inequality has reached levels never before known. According to the NGO Oxfam International, at the beginning of 2017, the eight richest people in the world possessed half of the wealth of humanity, some 3.6 billion people (Oxfam 2017). With the encyclical Praise Be to You, Pope Francis has added his voice to this mix, signalling that we can see signs that things are now reaching a breaking point, due to the rapid pace of change and degradation; these are evident in large-scale natural disasters as well as social and even financial crises, for the world's problems cannot be analyzed or explained in isolation. There are regions now at high risk and, aside from all doomsday predictions, the present world system is certainly unsustainable from a number of points of view, for we have stopped thinking about the goals of human activity (Francisco 2015, 19-20).

What is the civilisational dimension of this crisis? It is civilisational in that it is a crisis of the historical configuration of modernity itself. According to Edgardo Lander,

the anthropocentric, monocultural and patriarchal civilisational pattern, of limitless growth and systematic war against those factors that make life on Earth possible, is passing through a terminal crisis. The civilisation of scientific-technological 
dominion over so-called 'Nature', that identifies human welfare with the accumulation of material objects and economic growth without measure-whose ultimate historic expression is capitalism-has its days numbered. Its destructive dynamic of the commodifying of all life's dimensions, rapidly undermines the conditions that makes itself possible (Lander 2013: 27).

If the civilisational crisis is the result of the expansion of just a particular and determining civilisational pattern, humanity must move away from this singular pattern to incorporate a diversity and multiplicity of cultures, of ways of knowing, thinking and living, within the grouping of the networks of life.

On this planet, there are-despite 500 years of growing dominance by the modern colonial world system—other memories, histories, communities, peoples, subject and experiences that view life from other places. [...] other ways of understanding the relationship between humans and the rest of the webs of life. Here there are meanings that modern thought is incapable of understanding, because it simple sees them [...] as animism, as expressions of backwardness and obstacles to progress. These 'obstacles' today constitute the best possibilities for humanity to resist and stop this destructive machine called capitalism (Hoetmer, 2011: 71).

Pope Francis himself describes this wealth of existing cultures and civilisations as a "treasure of humanity", that "A consumerist vision of human beings, encouraged by the mechanisms of today's globalized economy, has a levelling effect on cultures. [...] In this sense, it is essential to show special care for Indigenous communities and their cultural traditions." (Francisco 2015, 112-114).

In order to understand the multidimensional character of the current crisis and open a new field for reflection on equally multidimensional alternatives, Ulrich Brand, and Markus Wissen have introduced the concept of the imperial way of life (2013; 2017, also see the article by Ulrich Brand in this book). By way of life, the authors understand the dominant patterns of production, distribution and consumption, but also cultural imaginaries, subjectivities and routines rooted in the everyday practices of a certain population. In this way, the concept seeks to combine structural dimensions with subjectifying and subjective dimensions and is thus differentiated from what is understood by lifestyle (Brand and Wissen 2017). By imperial way of 
life, the authors refer to a capitalist/modern/Western way of life, prevalent among the majority of the geopolitical Global North but also (and increasingly) present among the upper- and middle-classes of the South and in 'emerging countries'.

This Northern way of life is imperial to the extent that it presupposes unlimited access to natural resources, cheap labour, and the capacity for absorption of pollution and rubbish, as well as the entire planet's surface for merely a minority of the world's population. This access is secured through policies and laws, or through the exercise of force (Brand and Wissen 2013, 446). Praise Be to You arrives at the same finding when it states that "twenty percent of the world's population consumes resources at a rate that robs the poor nations and future generations of what they need to survive." (Francisco 2015, 75).

The success of this way of life in the imaginaries and subjectivities of broad segments of the world's population has aggravated the crisis, to the extent that the new middleclasses in countries such as China or India now also aspire to it, which leads these countries to search for where to outsource their high environmental and social costs, entering into a critical competition with the old capitalist centres (Wissen 2013).

If the civilisational crisis is due to the expansion of the imperial way of life on a planet with physical limits, the required alternatives necessarily lead to a significant reduction of material production and consumption, of pollution and of emissions, without thereby decreasing quality of life, as perceived subjectively. "We all know that it is not possible to sustain the present level of consumption in developed countries and wealthier sectors of society," says Francis $(2015,22)$. To this end, those ways of life that are alternatives to the imperial acquire special relevance. Brand and Wissen label them as ways of life in solidarity: ways of organising society far from the path traced by the paradigm of development and the development-growth-progress triad.

In Praise Be to You, Pope Francis adopts a critical posture in the face of the growth paradigm and the centrality of the market in the current world (Francisco 2015), while he recovers notions of development and progress in the line "integral and sustainable human development" in solidarity (Francisco 2015, 17). With this, the 
discourse of Praise Be to You places itself within the lines of alternatives to development or development alternatives, which identifies notions of growth, development and progress as pillars of an economistic, Eurocentric presence that was substituted, after the Second World War, for the more openly racist discourses of the Western civilising mission in the colonies, thus reorganising the world-system and ensuring the domination of capitalist centres. ${ }^{4}$

While the dominant discourse suggests that there is the possibility of social ascension for everyone via unlimited growth - that which has led us to the current civilisational crisis-in reality, the international division between work and nature shows that this is only possible for a segment of the world population. The majority are confined to the role of supplying cheap labour and primary materials and living with the social and environmental costs outsourced to their territories by a privileged minority. Pope Francis arrives at the same conclusion: "developing countries, where the most important reserves of the biosphere are found, continue to fuel the development of richer countries at the cost of their own present and future" (Francisco 2015, 42). Many from the South who enter into the universes of consumption during favourable cycles have a high chance of being expulsed from them in moments of crisis. At the same time, one of the symptoms of the civilisational crisis is precisely the generation of runaway inequality and, as a consequence, poverty.

As per Boaventura de Sousa Santos, in order to not waste the already existing diversity in the world during the search for the alternatives that necessary in the face of this civilisational crisis, it is necessary to undermine hegemonic knowledge and make other forms of knowledge visible, such as other ways of organising life and the economy. "It is not that we need alternatives, but that we lack alternative thought on alternatives" (2011a, 17). At the same time, we must understand that we are faced by modern problems for which there are not sufficient modern solutions (De Sousa Santos 2002).

\footnotetext{
${ }^{4}$ For a discussion on alternatives to development and development alternatives, see Lang and Mokrani (2011). For a more exhaustive critique of the different conceptions of human development, see Lang (2017). For the incompatibility between development and sustainability, see Brand/Lang (2015).
} 
It is therefore necessary to identify, preserve and protect, and, above all, learn to speak with vital spaces, social processes and communities that have not been entirely permeated by the dominant logics, be they Amazonian or agroecological communities in Europe, Japan, or the United State of America (Lander 2013, 28; Moreno, Speich and Fuhr 2015, 53). As a consequence, the civilisational crisis turns us to a political project of intercultural construction, in the sense of a critical interculturality defined by Catherine Walsh: an equally multidimensional project of transformation, that "affirms the necessity of changing not only the relations, but also the structures, conditions, and mechanisms of power that maintain inequality, inferiorisation, racialisation, and discrimination". It is about "reconceptualising and refounding social, epistemic and existential structures that put in place and in an equative relationship logics, practices and diverse cultural ways of thinking, acting and living (Walsh, 2009).

The way in which, in recent years, fundamental ecological concerns were reintegrated into the profit imperative via the green economy (Brand and Lang 2015) — which subjected the sustainability of life itself to the need for accumulation-suggests that it is impossible to achieve the objective of constructing sustainable conditions for life on the planet without transformation the dominant civilisational pattern through a political project of critical interculturality. This implies overcoming the epistemic violence that has characterised capitalist modernity, the imposition of only one valid way of knowing, and recognising the diversity of ontologies of ways of life. This is a challenge that includes questioning current definitions of poverty, in which those parameters useful to capitalism dominate. For example, there is the possession of money (income poverty) or even the volume consumed by a family (consumption poverty), instead of the existence of material conditions that allow for the reproduction of life-which could include fertile land, clean water and air, etc. Finally, it is also necessary to critically rethink what is understood by human needs and quality of life in different contexts. 


\section{Human needs and quality of life}

Since the 19th Century and even more so after the second post-war period of the 20th Century, when North-South relations were reorganized around the development-underdevelopment binary, the notion of quality of life that corresponds to the capitalist/modern/western way of life became hegemonic.

According to this perspective, human happiness would be strongly linked to a growing consumption capacity, because human necessity would equally follow an expansive trend. The notion of success that we have internalized has to do with our participation in unlimited consumption in this culture of access to everything, always (Welzer 2013) that obliges us to give ourselves to the abstract and anonymous exchanges of the globalized economy and its quasi-dictatorial conditions. Exchanges where everything is provided without anyone having an overview of the value chains, of the energy and matter invested in the transport, and of the working and environmental conditions involved elsewhere in the production of a particular product. When one buys a product, that information is not present. This abstraction, which separates the history of the product from its function as a commodity, is characteristic of practically all areas of modern societies. This principle of external supply brings us to a world without responsibility or accountability, where the only possible link between production and consumption is money, in turn another abstraction. It hides the relational fact that we all belong to the same metabolism with nature-making building sustainability all the more difficult (Welzer 2013: 244). In this way, the cultural dimensions of the globalized economy and its geopolitical configurations are surreptitiously inscribed in our societies.

It is worth asking how attractive it really is to participate in this race for the accumulation of material possessions, even when done successfully. Pope Francisco warns us that the consumerist paradigm "makes us believe we are all free as long as have a supposed freedom to consume (...) the emptier the heart of a person, the greater the need to buy objects, possess and consume" (Francisco 2015, 156.) The Austrian Veronika Bennholdt-Thomsen, who differentiates between production for money and production for life, reminds us of the important gaps in this model: 
In the planet's northern hemisphere, we are undoubtedly well supplied in material terms, in many aspects we are even saturated, and yet we have shortages. We lack human contact, a sense of closeness and belonging to a community that can provide us with security, as production for life would require. The great problems of our time are personal detachment, loneliness, existential anguish, as well as, for lack of emancipatory alternatives, the refurbishing of racist and nationalist imaginaries of communality (Bennholdt-Thomsen 2006, n.p.).

For the populations of the capitalist centres, who presumably benefit from being successfully included into the economic model, the dimensions of Mal Vivir are multiple, although rarely related at the discursive level with welfare or poverty: the constant acceleration of daily life causes not only alienation but other multiple negative effects on physical and mental health, even mortal ones, as well as a lack leisure time, for sharing and celebrating (Rosa 2013a).

These effects have reached alarming levels: while in Germany, 2,700,000 workers have experienced periods of burnout, in July 2015, the same phenomenon was experienced by $62 \%$ of the US work force, more than $45 \%$ of the medical doctors and $69 \%$ of male professionals in finance. ${ }^{5}$ A sixth of the German adult population live with panic attacks that interfere with their daily routine. ${ }^{6}$ In Japan and China, there is specific terminology for exhaustion related deaths or suicides and these countries have been forced to design public policy in response to these phenomena. ${ }^{7}$ At the same time, France and the USA are among the countries with the highest rates of depression. ${ }^{8}$ This data invites us to at least place some doubt on the quality of life offered by the path to success within the hegemonic model.

The desire to satisfy human needs, or at least people's 'basic needs', is a central pillar of the discourses surrounding poverty eradication that have justified the advance of development—or capitalist modernization-on the planet. The postcolonial development critic Ilan Kapoor (2009) has shown that the needs discourse ends up

5 shttp://www.gallup.com/businessjournal/184106/german-workforce-burnout-problem.aspx); shttp://www.statista.com/topics/2099/stress-and-burnout/, accessed 5 September 2017.

${ }_{6}^{6}$ shttp://www.economist.com/node/10329261), accessed 5 September 2017.

7 http://www.webmd.com/depression/news/20110726/richer-countries-have-higherdepression-rates\#1), accessed 5 September 2017.

8 shttp://www.taz.de/!5325096/, accessed 5 September 20177. 
acting as a colonizing tool. According to him, just the concept of 'basic needs' is an ethnocentric construction: it presupposes a human being devoid from social and cultural links, who is left with 'the most basic things' - a fiction of the 'state of nature'-while it is well known that many societies prioritize the sacred over the profane. Even under situations of material deprivation, they prioritize, for example, the construction of religious sites that give sense to their lives. This is corroborated by a peasant proverb from Burkina Faso "a full stomach fills neither the heart nor the soul. Instead, when the soul and the heart are in peace, they can calmly wait for food" (cited in N'Dione 2001, 49). The very notion of 'need' naturalises a particular conception of the human that is quite simplistic and monodimensional as a being who lives to 'satisfy needs'. Based on his long experience working with communities in Senegal, Emmanuel N'Dione radically questions the needs concept:

The ideology of development is totally built upon the idea that needs must be satisfied by any means, to the extent that development could be defined as the endeavour to progressively satisfy ever less 'basic' needs. From this perspective, developed people are the ones who have satisfied primary needs such as drinking, eating, healing, etc., and who then seek to satisfy new needs through the consumption of products that are less necessary. In reality, the satisfaction of a need engenders the dissatisfaction of tens and hundreds of other needs and son on, indefinitely. To begin from a need seems to lead us to an impasse. Needs alienate in the sense that they push individuals to looks ever farther and outside themselves, far from and outside the individual's community. The only real necessity, according to us, is the meaning and harmony of what one lives, where one lives, the people with whom one lives. This is a necessity that cannot be bargained. 'I do not have anything, hence I do not need anything' says the Moroccan proverb (N'Dione 2001, 49).

According to Ivan Illich (1990), the concept of needs has become central in the development discourse from the 1960s onwards. It is no longer about concrete and situated needs for specific people, but rather about generic or systemic needs that are precisely defined by specialized development experts and that in the end serve to delineate what is human from what it is no longer considered to be human, since it "degrades individuals' lives below the minimum standards of human decency" (Robert McNamara, WB president in 1972, cited by Illich 1990, 8). Soon, adds 
Illich, these minimum norms of human decency would be expressed in dollars and cents by a team of social scientists.

Moreover, the 'basic needs' discourse reflects the paternalism of modern/western social engineering, as it adopts as its premise as series of hierarchical dualities such as poor-rich, culture-nature, luxurious-basic. The focus of the NBI is based on the presence of a strong state, and the selection of needs to be measured is carried out by top down 'experts,' which leads Kappor to ask whether the goal is not to satisfy the needs of policy makers. The 'beneficiaries', in any case, are placed once more in a position of dependency, passivity and lack, without considering the possibility that they could define their own priorities or act upon them (Kappor 2008, 22).

\section{Poverty, underdevelopment and epistemic violence}

During the second post-war period, the development-underdevelopment paradigm introduced by the US government under Harry Truman (see the article of Alberto Acosta in this book) subdued the diverse ways of life, production, distribution and reproduction found across the planet to a unique accounting methodology and language-Gross Domestic Product - so that they could be expressed in comparable numbers. This represented an act of considerable symbolic violence because that indicator is based in the socioeconomic reality of the United States, England and Australia-a very specific reality that was imposed as global norm (Speich 2011, 15). Perceptions of the peoples of the South on quality of life, built throughout their own historical development and cultural parameters, was not considered. Instead, what was considered was the 'truth' expressed by the Northern indicators. This 'truth' was not just a perception of others that questioned the dignity of those defined as poor, but an official truth supported by science and by internationally renowned institutions.

Vandana Shiva, Indian ecofeminist, confirms that the modern and reductionist understanding of poverty that resulted from this process confounds two radically different realities: 


\section{Social Justice and Civilisational Crisis $\mid 40$}

It is useful to separate a cultural conception of subsistence living as poverty from the material experience of poverty that is a result of dispossession and deprivation. Culturally perceived poverty need not be real material poverty: subsistence economics which satisfy basic needs through self-provisioning are not poor in the sense of being deprived. Yet the ideology of devel-opment declares them so because they do not participate over-whelmingly in the market economy, and do not consume commodities produced for and distributed through the market (Shiva 2004: 3).

In this way, people are labeled as poor who grow their own food, build their own houses with local inputs, produce their own clothing instead of buying them in markets and use traditional technologies. Nevertheless, not only can these practices support a good quality of life, but are also preferable, according to the author, to the solutions offered by modern capitalism, for example in terms of sustainability:

This cultural perception of prudent subsistence living as pov-erty has provided the legitimisation for the development process as a poverty removal project. As a culturally biased project it des-troys wholesome and sustainable lifestyles and creates real mate-rial poverty, or misery, by the denial of survival needs themselves, through the diversion of resources to resource intensive commo-dity production (Shiva 2004, 3).

The omnipresent discursive machinery of hegemonic representations about poverty and underdevelopment has had powerful effects about Global Southern subjectivities, about the ways the people who are categorized as poor and underdeveloped, by the authoritarian opinion of experts, are and see themselves in the world. There is a big difference between lacking something and being defined as a deprived being. As told by a UN functionary to Ashis Nandy $(2002,116)$ "Many communities did not know they were poor until development agencies told them."

The moment the capitalist/modern/western way of life was erected as the norm in the comparative global accounting exercise that underlies the design of the GDP indicator, other ways of life, civilizations, and diverse forms of organizing society were labelled as deficient and 'poor.' The enormous development-underdevelopment dispositive, deployed from the 1950s onwards to fight poverty and hunger, systematically excluded the voices of the peoples, groups and communities that fell into the category of the poor. They were pathologized, infantilized and made visible 
only as objects of expert intervention. The statistical, economic and scientific discourses of these interventions lacked a subject. The relation that was established with the 'beneficiaries' of the hoped for 'development' was condescending, paternalistic and obeyed to a patriarchal logic, without any consideration to their selfperception, for example about their needs or quality of life (Escobar 2007, 265). This was especially the case with regards to the Green Revolution, that great technification and industrialization campaign that was carried out from the 1960s onwards. In this campaign, capitalist logic was expanded throughout large extensions of rural territory across the planet-always in the name of fighting poverty and hunger-with the effect that many peasants lost their lands, were impoverished and had to migrated to the cities (Mies 1998, 80; see also Shiva 1991).

Thus far, the ways of life, the ways of social organization, the knowledges and perceptions of the populations categorized as 'poor' have tended to be placed at 0 on the dial, reset at the moment when they became beneficiaries of 'help against poverty'. They have been made empty recipients to be filled with the canonized knowledge of development, accounting and technic experts. Against the construction of intercultural critique required by the current civilisational crisis, the "fight against poverty" has resulted in the systematic destruction of the cultural practices that exist at the margins of the market economy, "especially the practices of self-subsistence and reciprocity of local exchanges that have been so crucial for peasants, women and indigenous peoples" (Escobar 2007, 268). In the words of the Kichwa Ecuadorian Amazonian leader Carlos Viteri Gualinga,

Development $[\ldots]$ conceived indigenous societies [...] as groups that belong to a space-time that is considered to be 'traditional', 'peripheral' and 'primitive'. This is the reason why indigenous peoples are believed to belong to a culture of poverty, or what is commonly called 'the poorest among the poor'.

All of this implicitly insinuating that overcoming indigenous 'poverty' requires access to the 'benefits' of 'modernity', which path is 'market integration', the path that leads to development. For this, indigenous peoples must stop insisting in their 'nonprofitable traditions,' give up their local means of self-subsistence and forget about their capacities of autonomous management, to become a labour force, to allow free 
access to extractive activities of the subsoil and biodiversity, and to become dependent on the State, so that it solves their needs (Viteri Gualinga 2002: 4).

The act of simply naming these different ways of life without devaluing them is a semantic challenge: many times, these ways of life are called 'precapitalist', 'premodern' or 'primitive,' reproducing in this way the western notions of linear time, progress and 'lagging behind.' Alternatively, they are called 'ways of subsistence,' which suggests that they cannot produce more than what is strictly necessary to survive (Lander 2008, 221), even when production levels can respond to a deliberate decision to dedicate more time to activities other than production and the accumulation of material goods. For the purposes of this text, I talk of other ways of life that have not been completely permeated by capitalist logics. I am not only talking about rural communities in remote areas, but also about low-income urban sectors with the most varied cultural backgrounds and that carry out activities that do not correspond to capitalist/modern/western rationality. For example, alternative ways of exchange and money circulation, as well as other ways of spending time and sharing, such as parties and leisure, that signal a relative and partial independence from the imperial way of life. These ways of life could be carried out by migrant indigenous and afro-descendent indigenous communities that have adopted communitarian practices in the city, or by populations of self-built neighbourhoods that are generally undermined as favelas or slums, and that are generally represented as paradigmatic places of poverty and Mal Vivir, even though.

Any marginal neighbourhood in Nairobi or Jakarta is more culturally vibrant than the most sophisticated cities and suburbs of the central United States. How can a person whose main locus of sociability is a privately-owned mall—or worse, the local supermarket or parking lot-be condescending with the poverty of any other person anywhere in the world? (Esteva, Babones, Babcicky 2013, 140).

Pope Francisco also highlights quality of life dimensions that are usually rendered invisible by the hegemonic gaze over urban marginal areas:

The feeling of suffocation that is produced by urban agglomeration in residences and spaces with high population density is counterweighed if close and warm human relations are developed, if communities are created, if the limits of the 
environment are compensated when people have an inner sense of belonging to a communal web. In this way, any place stops being hell and becomes the context for a decent life. (...) In these conditions, many people are capable of knitting webs of belonging and coexistence that transform overcrowding into a communitarian experience (Francisco 2015, 115-116).

However, those who do not consume what is considered to be necessary by the experts in charg of defining human basic needs, because they, for example, produce a good share of what they require, are not only considered to be 'poor', but are left out of what has become a hegemonic definition of what is considered to be human, as per homo economicus: those who act rationally to maximize their consumption potential of goods and services providing the highest degree of utility. In this way, their ways of life are in danger of being categorized as infra human and indecentand therefore disposable (Illich 1990, 10).

While the development/underdevelopment dispositive disqualifies alternative practices and ways of life as 'poor' because they remain, at least partially, outside of the realm of accumulation, from the perspective of these alternatives, their value is located precisely there, in their capacity to persist outside of the dominant paradigm of satisfaction through consumption and instead respond to different rationalities and desires. I do not want to idealize here: throughout history, most of these ways of life have been systematically cornered, their cultural trajectories distorted and negated, and the common resources that are essential for their reproduction have been dispossessed. This has been a type of dispossession taking place under the highly unequal appropriation framework that is implied in the imperial way of life. My objective here is also not to point to an exemplary model for us to follow. On the contrary, the task is to de-universalize and re-contextualize our understandings of what a good life is. Nevertheless, when considering the need for civilizatory alternatives, it seems crucial to recognize, speak and exchange with epistemological and ontological systems, as well as with cosmovisions and ways of life that lay outside or at the margins of the capitalist/modern/western civilization and that have different understandings about happiness, quality of life, and the meaning of human coexistence. 
Social Justice and Civilisational Crisis | 44

\section{Socialism, an alternative?}

During the course of the 19th and 20th Centuries, the discourse about systemic alternatives turned around socialism: a system demanding social equality and justice. To what extent is socialism, or was socialism, such an alternative in the context of today's challenges? The dominant interpretations of Marxist thought, that inspired the politics of the soviet bloc in the 20th Century, shared the same patterns of colonial and Eurocentric knowledge upon which the colonial/capitalist modern world system was built.

The actually existing Marxism, when adopting the conceptions and practices of truth, science and technology that have been dominant in the western world, has encountered insurmountable limitations in its capacity to critique capitalist society, not only as a way of organizing property or exercising power, but also as civilisational model. In spite of its depth and radicalism, the Marxist critique of the world of capital - for adopting the notion of progress, the idea that Western civilization is the major expression of man's creative potential, for believing that European society represents the highest point of the inexorable process through which historical laws are deployed - was not capable of distancing itself from the particular cultural option offered by the West and by capitalism. It accepted capitalist society as a historical inevitability and as a historical progressive step towards liberation and human happiness. This lack of critical distancing from the dimensions and basic constitutive aspects of capitalist society [...] led the actually existing Marxism to the impossibility of thinking a global alternative to the highly centralized and unidimensional productivist technological society that has been historically developed by the regime of capital (Lander 2008, 11).

The political practice of the soviet bloc towards the different ways of life that existed in its area of influence was based on universal and culturally hegemonic pretensionsin the same way that the capitalist policies of the time were. These hegemonic pretensions were not only reflected in the policies of persecution and annihilation of the cultural diversity that existed in the Soviet Union's territory, but also in the policies of the Third International towards Latin America (Meschkat 2010; Lander 
2007), to give an example. In this way, the hegemonic developmentunderdevelopment paradigm encompassed both of the systemic proposals competing against each other in the Cold War.

The mission to 'civilize' others stopped being ethically acceptable from the second postwar period onwards. In this context, the eradication of poverty became one of the central discourses used to legitimize massive processes of primitive accumulation and the expansion of the capitalist/modern/western way of life. In an act of epistemic violence, the categorization of culturally different populations as 'poor' by the scientific/western expert discourse made these populations inferior and infantile: they went from being subjects of their own history to becoming the objects of intervention and assistance to all type of institutions. Not only were the voices of these populations devalued, but also their systems of knowledge, cosmovisions and non-capitalist ways of production, reproduction and care.

Despite their anti-systemic rhetoric, the dominant 20th Century interpretations of socialist thought, as well as their governmental practice in different places of the world played a role in modernity's monoculture colonial expansion. Their blind faith in science and Western technology, their pretension to objective truth and their historical determinism towards socialism, as well as their participation in the intersystemic race for economic growth and higher productivity have helped to legitimize the central tenants of the modern/western/capitalist paradigm. ${ }^{9}$

\section{Latin American progressivisms and the civilisational crisis}

Over the last fifteen years, Latin America has been a source of inspiration and hope for a good portion of those forces concerned with social justice in the world, whether they consider themselves of the left or not. Successive electoral victories of forces selfidentifying as leftist or 'progressive' in a number of countries, beginning the victory

\footnotetext{
9 Today, the relativization of these modern/western pretensions of truth from a decolonial perspective confronts an enormous task: differentiating itself from the relativizing strategies of alt-right movements that are become stronger in different parts of the world. These movements locate their emotional perception at the level of, or above historical or demonstrable facts. Donald Trump, the US president, is one of the best representatives of these ideas.
} 
of Hugo Chávez in 1998, configured the subcontinent as an exceptional geopolitical space in a world ensconced in neoliberal hegemony, which promoted the possibility of profound social transformation. The relative simultaneity of self-proclaimed postneoliberal governments and attempts to reorient regional integration even allowed for thoughts of profound transformation reaching further than just the national scale. This exceptional historic grouping was the result of the commitment of electoral majorities, constituted by anti-neoliberal and emancipatory movements that the continent had known since the first decade of the new millennium. After a decade focused on resistance, this commitment sought to follow the path of transformation through the occupation of the machinery of state by way of electoral victory and the exercise of government.

In response to the civilisational crisis, alternative paradigms emerged to the modernWestern one that gave rise to it, such as Sumak Kawsay (generally translated as Buen Vivir or Good Living, although it more accurately translates as 'life in fulness'), plurinationality, or the rights of Nature, embodied in the constitutions of countries such as Bolivia and Ecuador, and understood by at least some schools of thought as alternative civilisational projects (Acosta 2009; Gudynas 2011c; Farah and Vasapollo 2011; Prada 2013). The following quote exemplifies the expectations that arose around these paradigms:

In the same way that the plurinational state is the alternative to the liberal contractuality of the modern state and interculturality is the condition of possibility for society to recognise itself in the differences that constitute it, Sumak Kawsay is the alternative to the capitalist mode of production, distribution and consumption. [...] Sumak kawsay proposes, furthermore, a different form of relationship between human beings in which selfish individuality must submit to the principles of social responsibility and ethical commitment and in relation to nature, which is recognised as a fundamental part of human sociality. Thus far, it is the only coherent discourse and practice that can stop the predatory and inhuman current of capitalist accumulation, that at the current pace has become a threat human life on the planet (Pablo Dávalos cited in Prada 2013, 45).

These alternative paradigms found multiple echoes across the planet, from Europe to the entire geopolitical South. However, in the Andean nations, they quickly ran into the limits of realpolitik and various resignifications by government. The declarations 
of plurinationality and interculturality of the Bolivian and Ecuadorian states, that in their moment marked new horizons for transformation in terms of intercultural construction, still ended up subordinated to the intrinsic logics of state apparatuses that suddenly had to manage-precisely because another important innovation consisted in the strengthening of the role of the state and its expansion in the face of the market - a counter-current of certain neoliberal creeds.

In retrospect, it can be said that much of the longing for change from Latin American emancipatory social movements ended up truncated in governments in which, despite their progressive or revolutionary statements, coexisted with a wide range of currents and political practices, including conservative and neoliberal ones (Gago and Sztulwark 2016). The commitment to finance social transformation with intensified export incomes from primary materials, which followed a neo-developmental and extractivist model, imploded with the crash in commodity prices in 2014. At the same time, the political-structural implications typical of the extractivist and rentier models drastically limited the possibilities of transformation, imposing the centralisation of political power, clientelism, and corruption as well as a paternalist logic intolerant of dissent and plural debate (Meschkat 2015). Finally, in the context of extractivist neodevelopmentalism, the recommendation of Pope Francis to "listen as much to the clamour of the earth as the clamour of the poor" (Francisco 2015, 39) was not observed. Environmental justice and the transformation of societal relations that preyed on nature were sacrificed, specifically in the name of social justice and the eradication of poverty (Gudynas 2015a; Svampa 2013), which was exemplified in the recurrent phrase of president Rafael Correa to justify the expansion of the petro-frontier or the introduction of mega-mining in Ecuador: "Misery cannot be part of our identity, and we cannot be beggars sat atop a sack of gold.” 10

Despite that, even today, in great swathes of the world, Latin American progressivisms continue to be perceived as political experiments of the left. This is due, on the one hand, to their ostensible anti-imperialism, but also, and in great measure, due to their success in reducing poverty and inequality. It is very present in

10 http://www.andes.info.ec/es/actualidad/9675.html». Accessed 5 September 2017. 
the official discourse of governments, but is also attested to by the statistics from international organisations such as the Economic Commission for Latin America and the Caribbean (CEPAL), with social justice being one of the traditional and core concerns of the left (Sangmeister 2008; Cameron 2009; Birdsall Lustig and McLeod 2011; Grugel and Rigirozzi 2012; CEPAL 2012; Jiménez and López Azcúnaga 2012; Lustig, Pessino and Scott 2013; Wahl 2016).

What then happened to the so-called 21st Century Socialism, to which Venezuela, Bolivia and Ecuador subscribed over the last decade and a half in the face of the civilisational crisis? For as much as it has only taken on a few of the political characteristics of 20th Century Socialism, such as state-centrism, the central role on the part of the governing party that blends into the state apparatus, and the intolerance of dissent, while it has implemented openly capitalistic economic policies, 21 st Century Socialism has been a faithful heir to its predecessor in its colonial, homogenising, and modernising perspective on poverty.

\section{Plunder by Social Policies-The case of Ecuador}

While the plunder that took place in the context of the extractivist/neodevelopmental model in Latin America has encountered much criticism, this has not been the case for the plundering that originated in the framework of progressive social policies against poverty. On the contrary, these have been praised by many leftist voices, despite the fact that when applied in territories not entirely permeated by capitalist logics, such as the Ecuadorian Amazon, they result in new encroachments.

The Citizens' Revolution (La Revolución Ciudadana), in the name of reducing poverty, plundered Amazonian peoples of their own resources for health and education, and continued with the destruction of their non-monetised economies that had already been the targets of oil companies, pushing the circulation of money into new areas, for example, through the Human Development Grant (Bono de Desarrollo Humano-BDH).

An analysis of health, education, $\mathrm{BDH}$ and infrastructure policies in the north of the Ecuadorian Amazon (Lang 2017) shows how a social policy managed centrally by the 
state, which does not aspire to critical interculturality and does not differentiate between contexts but has modern pretensions of universality, can end in plunder, reducing the quality of life of the communities and expanding the territorial penetration of capitalist social relations. Thus, the health policies of the Citizens' Revolution, in insisting on the principal role being taken by the state, eliminated the extensive networks of health promoters located in jungle communities, with first aid kits and facilities for first aid, substituting them for monthly visits by staff from the Ministry of Health.

Education policies eliminated what had been built over decades in terms of intercultural bilingual education, developed between Indigenous organisations and the ministry, in favour of Schools of the Millenium-large, centralised and wellequipped schools that nevertheless lost all links to the community (Torres 2017). Consequently, the abstract and equally universalising knowledge instilled in the students made them lose their sense of the life in the community, under parameters of sustainability, while preparing them to migrate to the city and sell their labour there. With the pretence of bringing the presence of the state to the entire national territory, the $\mathrm{BDH}$ (a monthly payment from the government to the poorest according to certain criteria), deeply penetrated the jungle. It had the effect of increasing the dependence of the community on money and processed foods, reconfiguring patterns of masculinity and femininity around the consumption of alcohol and prostitution, reducing their autonomy, and weakening traditional networks of subsistence. Finally, the three Cities or Communities of the Millenium-Pañacocha, Playas del Cuyabeno and Dureno-constructed by the correísmo (Correa-ism) as emblematic projects to fight poverty in the oil extraction zones in the northern Amazon, were an imposition by the government on Indigenous communities. By deconfiguring their rhythms of life; disciplining quotidian and territorial habits; thoroughly restructuring relations with space, time, nature, work, money and the community itself; and causing division between members of the community and family meant an integral and profound separation from their means of material and symbolic reproduction (Lang 2017; Bayon and Wilson 2016; Cielo and Vega 2015; Cielo, Coba and Vallejo 2016). In this way, these social policies 
orchestrated by the state and oriented toward modernisation and developmentalism caused a significant loss with respect to ways of life that prioritised sustainability and social relations not entirely permeated by capitalism. It was implemented without consultation with Indigenous communities. The definition of the needs of these communities was in the hands of ministerial bureaucrats, aligned with international parameters to combat poverty and their respective indicators. They dispensed with an authentic open dialogue with the supposed beneficiaries, who were established as 'poor' and given no voice. In this regard, Praise Be to You says:

Attempts to resolve all problems through uniform regulations or technical interventions can lead to overlooking the complexities of local problems which demand the active participation of all members of the community. New processes taking shape cannot always fit into frameworks imported from outside; they need to be based in the local culture itself. [...] There is a need to respect the rights of peoples and cultures, and to appreciate that the development of a social group presupposes an historical process which takes place within a cultural context and demands the constant and active involvement of local people from within their proper culture. Nor can the notion of the quality of life be imposed from without, for quality of life must be understood within the world of symbols and customs proper to each human group. (Francisco 2015, 113).

The agenda of Rafael Correa's government has not only been developmentalist in material terms-prioritising the modernisation of infrastructure and measures that are easy to identify statistically—but it has also been so in symbolic and epistemological terms. The discounting of other ways of life not entirely permeated by capitalist relations, such 'the poor' and their consequent 'eradication,' with the aim of generating new markets and new groups of consumers is one of the central ideas of the word development agenda since the end of the second world war. What it produces are new enclosures, multiple forms of dispossession that mean much more than simply privatisation, as is suggested by the image of a fenced off property. It means the forced separation of people and communities, in their social and cultural relations, from the resources and means they need for the symbolic and material reproduction. It is not unusual for the state to be an agent of dispossession: since the 17 th century, these enclosures were frequently effected by state actors through 
economic, legal, or technological mechanisms, or simply depriving people of their spiritual anchorage (Federici 2015; Helfrich 2016).

The case of Ecuador is particularly instructive, given that the Citizens' Revolution was characterised by explicitly seeking to universalise social protection through public services, in contrast to other progressive Latin American countries that weakened universal social provision as a right, encouraging privatisation of insurance, pensions and health services through the providing money and consumer indebtedness. ${ }^{11}$ For example in Brazil, "the population's access to potable water or adequate sanitation has improved little in the last decade. In comparison, the possession of consumer goods, such as mobiles, washing machines and computers has skyrocketed" (Lavinas 2014, 40; see also CEPAL 2013).

In Ecuador, the claim made by the most important actors in the anti-neoliberal struggle dealing with the 'return of the state' has strongly positioned neoKeynesianism as the only alternative to neoliberalism. I claim that the Citizens' Revolution deal with this by promising the implementation of a European-style welfare state of the 50 s or 60 s throughout the entire national territory, including the most remote parts of the Amazon.

This promise was accompanied by a vision of welfare associated with the Fordist imaginary of that time, with its technological optimism, unshakeable faith in progress based on industrialisation, and the delegation of redistributive and regulatory work to a paternalist and patriarchal state. However, in the 21 st century, not only does this vision of industrialisation, intensive exploitation of 'natural resources', and unlimited growth need to be questioned, especially in the wake of the civilisational crisis, but it would be very difficult for this model to become possible in an enduring form in a small country in the geopolitical South without a profound transformation of the international division of labour and the environment.

\footnotetext{
"Recent publications, however, show how, particularly in the Ecuadorian health sector, certain dynamics have led to a concentration of capital in private hands, for example, certain prepaid medical companies (Dávalos 2016, Iturralde 2014).
} 
In the case of Ecuador (as in other Latin American progressivisms), the promise of the welfare state, on the contrary, was conditioned on a deepening of the extractivist model, as it was to be realised with an increase in oil and mining income. What is obvious in this logic is that, firstly, the modern/Western or imperial way of life, which is sold to us as a generalisable ideal, was only possible in the North at the expense of the peoples of the geopolitical South. Secondly, its expansion only deepened the civilisational crisis and its catastrophic effects in terms of the destruction of ways of life and the expansion of violence in social relations, instead of increasing welfare.

This conditioning on the extractivist model had two effects: the disregarding of actors that defended relations of harmony and equilibrium with nature and a specific redistributive model that concentrates power. The official discourse systematically discounted Indigenous people and groups of ecologists that defended other types of relationships with nature, thus weakening the organisational fabric and the public voice of these sectors. A part of this dismissal was the discursive construction of Indigenous peoples as the poorest group in the country, forcing onto them imaginaries that situated the city as the place of success and progress, in contrast to the country as a place of backwardness and poverty. Thus, the trend toward urban migration and unsustainable ways of life focused on consumption was reinforced (Lang 2017).

The case of Ecuador clearly shows that despite decades of debate and proposals about alternative indicators and, in recent years, the measurement of Buen Vivir (see, for example, Albó 2012, León 2015, Guillén 2016), so-called 'human needs' continue to be established from above, in a way that is colonising, technocratic, undemocratic, and definitely not intercultural, while taking into account neither the voices nor parameters for welfare of Indigenous peoples and other culturally different groups.

It is a perverse cycle: the state, in the name of 'fighting poverty', generates tax revenues to build schools, roads, etc, but commits multidimensional plunder and pushes impoverished populations to sell their labour for a wage, pushes them into informal work, and pushes them into depending on the state and/or the bank through debt. What is achieved, without the shadow of a doubt, is the expansion of financial 
markets toward the poorest strata so that they become consumers of goods and services and thus contribute to the accumulation of capital in these areas, for example through very profitable microcredit that charges between $20 \%$ and $40 \%$ annual interest, according to institutions (Lavinas 2014; Welzar 2013: 235). Welzer criticises this type of credit system, but also conditional cash transfers such as the $\mathrm{BDH}$, as strategies against poverty: "If a seventh of humanity hinders the expansion of the market economy in this way [having less than a dollar a day to spend], the path to transforming the poor into participants in the market is obvious: you simply have to give them money" (Welzer 2013: 236).

In this way, the politics of poverty eradication played a key role in channelling the transformative social energy of the previous decade toward its repurposing for capital accumulation: driving the transformation of women and men, who were living for the most part from subsistence work, into workers, consumers and debtors, creating dependencies and destroying precisely those local and community forms of resilience that were not monetizable. At the same time, the model for control and redistribution of profits by the central state consolidated an authoritative form of redistribution, as opposed to other redistributive modalities that disseminate power horizontally rather than monopolising it. This formed an inclusive authoritarianism, as we have just seen, in the definition of the needs of populations. The application of sets of indicators that take as a 'universal' point of reference capitalist/modern/urban ways of life centred in goods and services necessarily distorts results related to the quality of life of Indigenous peoples, which continues the modern/Western espstemicide (De Sousa Santos 2010; Moreno, Speich and Fuhr 2015).

At the same time, the promised 'inclusions' - in the sense of 'exiting poverty' and accessing opportunities for consumption, will always be vulnerable and easily reversed while that which is redistributed is limited to oil surpluses, such as during a crash in international commodity prices as seen recently. Furthermore, as long as the construction of interculturality, understood as the process of mutual recognition, understanding and enrichment of different ways of existence in the same hierarchy in order to construct a 'multiverse' (Arturo Escobar), is not a transformational project 
assumed by the whole of society, including its institutional expressions, this promise of 'inclusion' will always clash with existing barriers of racism and discrimination.

That is to say, this construction of interculturality would be susceptible to revert to 'inclusion' in labour markets and consumption in terms of the framework of capitalism's cycles of crisis and would be further limited by racism. On the other hand, it could be difficult to return the loss of autonomy, self-sufficiency and dignity caused by the dispossession of one's own capacity to generate welfare, understood in a radically different way. In this way, women and men of communities dispossessed by state actors of their own capacities and the material foundations necessary to generate collective welfare would be left in complete destitution.

With its hyper-presidential and clientelistic practices, but also with its insistent invitation to leave absolutely everything in the hands of a redemptive state, correísmo has further deepened the colonial/patriarchal political culture that already preceded it in Ecuador. Policies for poverty eradication were erected over an idea of the passive citizen, individualised and universal, whose involvement in politics is limited to the vote, and that only recognised generic and abstract human beings that sought to satisfy their 'basic needs'. The filter of perception imposed by a story centred on the statistical representation of successful government development hid the numerous processes of dispossession in the material, social, political, spiritual and symbolic plane that communities suffered for their 'inclusions', founded, furthermore, in the expansion of extractivism.

The advance of the state into Amazonian territories strengthened a certain way of conceiving the political, based on a series of epistemological and ontological compromises with the heritage of capitalist modernity, despite the fact that it has called itself 'plurinational' and 'intercultural' since the 2008 constitution. It is a way of conceiving the political that defends the existence of the state as a place of central enunciation, that claims the monopoly of force, that homogenises and does not diversify, that orders, rules and does not deliberate. It is expressed though the formulation of a supposed 'general interest', that often corresponds to the interest of stabilising conditions for the accumulation of capital. 


\section{Buen Vivir and social alternatives}

Building social alternatives requires that we overcome the limits of the hegemonic thought promoted by the left since the 20th Century (and well into the 21 st Century up until today) that has drastically reduced its utopian and alternative potential. It requires that we recognize how crucial the diverse modes of living, forms of thinking, and knowledge that exist on the planet are. It also requires that we recognize how urgent it is to build sustainable (rather than predatory) relationships with of Nature and that this sustainability goes hand in hand with forging intercultural relationships that relativize and interrogate the paradigms of the modern/capitalist concept of wellbeing. Ultimately, it requires that we distance ourselves from any type of incremental narrative on the eradication of poverty that inscribes the fight against poverty within a teleological line of continuous progress ("there are still so many poor people"), while glossing over the very processes that continue to generate inequality.

The advances that Latin American countries like Ecuador and Bolivia inscribed in their constitutional processes, which were the result of a long cycle of popular and indigenous fights in the 1990s, were to a large extent stalled by the internal logics of the State and subsequent 'progressive' administrations. Instead of using those constitutions as a starting point for a deep, integral, participatory and deliberative transformation - which, since it was an experimental process, made it impossible for such changes to be implemented in the short term without any sense of incoherence or setbacks, let alone with the aim to conform to neoliberal criteria of 'quality' (read efficiency) - this transformation was limited to the State and to capitalist modernization. Those progressive governments reinterpreted powerful concepts such as Buen Vivir, or Good Living, in the light of productivism. Their adherence to the simplistic dichotomy 'neoliberalism versus neo-Keynesianism'-or market versus State-led them to completely ignore, and even fear the enormous potential the community has when it comes to building social alternatives as breeding grounds for modes of production, reproduction and (self-) governing that are real alternatives (Caffentzis y Federici 2015). 
Learning from the experience of Latin American progressive movements from the perspective of social alternatives means redefining the concepts of poverty and wellbeing from the point of view of critical thinking. It also means getting rid of any unilateral or universal notion of human need and taking some distance from the logics of metrics used to represent the complexity of the world and to inform political decisions based on reductionist statistics. This does not mean rejecting the quantitative approach altogether; rather, it means questioning its almost systematic role in our representations of reality, its supposed 'technical neutrality' and overbearing presence in political decision-making. Meanwhile, other forms of knowledge should be recognized, valorized and made more visible.

The multiple and diverse processes of social experimentation capable of leading us to social alternatives will most likely not happen in a straightforward, measurable and orderly fashion - as the hegemonic parameters of good governance would have it. Such processes should be granted the right to fail without being systematically nipped in the bud for not succeeding right away, and they should give us the opportunity to learn from those mistakes as a collective entity. To do so, one condition has to be met: the preservation and (re)construction of grassroots political communities of all shapes and sizes that are based on trust and collaboration, rather than competition.

\section{Rethinking social justice and redistribution}

How can we get from this critique to a different understanding of redistribution, equality and inclusion, that is to say of social justice—key themes for the left-that doesn't have the same effects and allows us to move toward the construction of alternatives in the context of the civilisational crisis?

A first step is to refute the grand modern narratives of poverty and wealth, contrasting them with integral notions of Buen Vivir that accommodate diversity. A single pattern of Buen Vivir cannot exist without colonisation and domination. Therefore, we must think about alternatives that are plural and situated. This, at the same time, could form the foundations for a critical intercultural understanding of well-being. This means, as a first step, de-universalising, democratising and radically 
contextualising the discussion of human needs that ought to be widened in all dimensions, including affective, relational, spiritual and social needs.

In order to re-signify notions of poverty and wealth, it is necessary to hear the voices of those actually involved first-hand, to understand them as autonomous political subjects and not as 'target groups', clients or passive beneficiaries, as well as to recognise the particularity and incompleteness of 'expert knowledge' and its coloniality whenever it is postulated as universal and objective. In this sense, it becomes necessary to unlearn the mental structures that consider quantification and accounting as the privileged way of perceiving reality and see specifically that which statistics do not illuminate. It must be understood that statistics do not only construct the object they measure, but circumscribe reality to that which is easily measurable, rendering invisible and finally excluding that which is immeasurable (Peréz Orozco 2014: 71). A step in this direction consists in shining a light on all exchanges and flows - even if they are not monetarised and do not obey logics of profit — as well as all forms of unpaid work that capitalism makes invisible while being sustained by them (Salleh 1997; Biesecker 1998; Mies 1998).

It is essential to distinguish between the 'two poverties' identified by Vandana Shiva and stop identifying those groups that give great weight to subsistence, selfproduction and traditional technologies as poor. We mush radically differentiate these groups that to a large extent still maintain their own sociocultural contexts from the millions of people who were stripped of them by the expansion of developmentalist logic and therefore need to not only resort to subsistence, but also reconstruct new interdependent relations and new senses of belonging. The civilisational crisis forces us to reconstruct from the margins, focusing the social creativity caused precisely by the circumstances of the crisis. In the words of Esteva, Babones and Bacicky:

The development crisis [of the 80s] took many people that had been conditioned to depend on an income and the market from their paid positions in the formal economy, people who were lacking in a social environment that would allow them to survive without the market. The margins are now confronted with the difficult task of relocating these people This process poses great challenges to everyone, but 
it also offers a creative opportunity for regeneration, once they discover how much they can help each other mutually $(2013,132)$.

Also, in the case of popular urban cultures solely defined from their lack as 'poor', it is crucial to recognise, value and make visible not only the mechanisms of survival they have generated, but the alternative sociabilities and social wealth that they build in contexts lacking in material resources and often in tension with modern/Western possessive individualism (Moreno 2000; Rodríguez 2013; Esteva, Babones, Babcicky 2013, 137).

In the context of the acute planetary environmental crisis, the reduction in the consumption of materials and energy and the decreased production of pollution, rubbish and emissions are necessarily the common denominators for these plural civilisational alternatives, keeping in mind the existing inequalities in this regard between the geopolitical North and South. Constructing sustainability means that the protagonists of the imperial way of life learn-in technological, philosophical, economic/productive and social organisational terms-about the communities and cultures, whether rural or urban, that manage to live in harmony with less, without which none of them could be established as a universal model to follow. A prior condition is the generation of conditions for a respectful intercultural dialogue with these other ways of life, conditions that allow them to express themselves with their own criteria, away from the mechanism of 'development/sub-development', of racism and inferiorising paternalism. In his reflections about an epistemology of the South, De Sousa Santos proposes the concept of ecology, understood as "the practice of aggregation of diversity through the promotion of sustainable interactions between partial and heterogenous entities" $(2009,113)$.

Another consequence of what has been expressed so far on the road toward emancipatory reflection in terms of civilisational alternatives, would be the recognition that the dominant version of the redistributive paradigm of the traditional left, understood as the grand alternative narrative to capitalism during the course of the 20th century, is in reality a part of the anthropocentric, monocultural and patriarchal civilisational pattern that the multidimensional crisis we are currently living through calls into question. If the Marxist tradition was participating in the 
implementation of the machinery of 'development/sub-development', if even the inter-systemic competition of the Cold War boosted the centrality of economic growth as a parameter for success of a society, it also becomes necessary to carefully review our way of understanding inclusion, equality and redistribution.

The permanent and exacerbated production of inequality, as described by the Oxfam report at the beginning of this work (Oxfam 2017), without a doubt constituted one of the central effects of the civilisational crisis, given that it gravely affects the conditions for survival of wide sectors of the world population. Likewise, democracy becomes impossible due to the concentration of so much power in so few hands and it becomes less and less possible for women and men to be able to exert an influence over the environment that affects them through the channels of representative democracy. In this sense, yearnings for equality and redistribution are, without a doubt, extremely valid if we understand them as the reestablishment of a necessary equilibrium.

Nevertheless, claims of equality and redistribution are usually expressed in terms of the redistribution of money and 'resources', that is, within the format provided by capitalist relations to conceive the materiality necessary for the reproduction of life, to understand property and relations with nature. Taking as a starting point the civilisational crisis and the need to construct sustainability within interculturality, it forces us to ask within what are the excluded intended to be included, given that the omission of this question easily sets the scope for the inclusion of a greater number of people in the hegemonic imperial way of life, further aggravating, no doubt, the crisis. What is commonly understood as inclusion, as development, according to Esteva, Babones and Babcicky is often synonymous with the incorporation of certain populations into the world market, which implies their cultural transformation into economic beings and the extinction of their previous ways of life $(2013,128)$. This should lead us to read between the lines of international organisations' proclamations of poverty reduction, such as that of the UNDP in the context of the Millennium development Goals (NDP 2015), in order to understand their implicit meaning. 


\section{Social Justice and Civilisational Crisis | 60}

Along the same lines, the prospect of expanding "access to goods and services"- so central to social policies—supposes 'universal' welfare parameters that in reality often correspond to urban/modern ways of life and, when implemented, entail a profound reconfiguration of forms of production and reproduction, of networks of life, without 'beneficiaries' having knowingly made a decision.

Can social justice really consist in everyone receiving exactly the same quantity of goods, services and resources? How to include into this outlook the diversity of needs according to context, in accordance with the construction of transformative interculturality and Buen Vivir in plural? Instead of redistribution in the terms of capitalist society operated by the liberal state, it would seem more appropriate to think of restitution, or better yet a reappropriation from below, of the materiality necessary for the reproduction of life based in diverse ways of life-and in the respective terms that these ways of life pose.

To give an example: land recovery-for instance, a hacienda that in the past was expropriated from Indigenous communities— can be given in terms of property titles, in which each family member becomes the owner of their plot, which corresponds to the principle of redistribution, or in terms of reappropriating a collective and inalienable territory in common that could be administered by communitarian norms and procedures. While the first solution is highly vulnerable to the resale of land in crises, and in the end to new interests of capitalist appropriation, the second subtracts the territory from the logics of commodification, it decommodifies it and opens the possibility of other ways of life.

It is in this sense that a redistribution of money, such as the conditional cash transfers and funds that prevailed in Latin American progressivisms, only reinforces and expands capitalist relations and thus deepens the civilisational crisis. The redistributive paradigm as central of the left is typical of the post-war era, of Fordism, and of the welfare state.

The civilisational crisis we are living through presents us with challenges that go for beyond redistribution: in the first place, it requires opening the classic redistributive paradigm to other dimensions, for example, redistribution of time and work in all its 
forms, as proposed by several feminist currents (Haug 2013). Then it suggests the decentralisation of the state as an actor of redistribution and wagering on the dynamics of reappropriation and reconstruction from below, territorialised and capable of persevering through time and expanding horizontally. But above all, it requires a profound multidimensional transformation that reorganises the coexistence of humans and other living beings around the sustainability of life.

\section{Bibliography}

Acosta, Alberto. 2009. "Derechos de la naturaleza y buen vivir: Ecos de la Constitución de Montecristi”. Pensamiento Jurídico, No. 25: 21-27.

Albó, Xavier. 2012. Suma Qamaña = convivir bien. ¿Cómo medirlo? Consulta: 13 de septiembre de 2017. http://www.plataformabuenvivir.com/wpcontent/uploads/2012/07/AlboSumaQamanaMedirlo.pdf

ACNUR. 2017. Desplazamiento forzado alcanza un nuevo récord. Consulta: 13 de septiembre de 2017. http://www.acnur.org/recursos/estadisticas/.

Bayón, Manuel, y Daphy Wilson. 2016. "Millennium Cities: Staging the Origins of 21st Century Socialism”. Cenedet Working Paper, No. 7 (febrero), (Quito: Centro Nacional de Estrategia para el Derecho al Territorio (CENEDET).

Bennholdt-Thomsen, Veronika. 2006. "Subsistenzwirtschaft, Globalwirtschaft, Regionalwirtschaft". En Maren Jochimsen y Ulrike Knobloch, edit., Lebensweltökonomien in Zeiten wirtschaftlicher Globalisierung, 65-88. Bielefeld: Kleine Verlag.

Biesecker, Adelheid, y Uta von Winterfeld. 1998. "Vergessene Arbeitswirklichkeiten”. En Willy Bierter y Uta von Winterfeld, edit., Zukunft der Arbeit - welcher Arbeit?, 34-53. Basilea: Birkhäuser.

Birdsall, Nancy, Nora Lustig y Darryl McLeod. 2011. "Declining Inequality in Latin America: Some Economics, Some Politics”. Center for Global Development Working Paper, No. 251 (mayo). (Washington D. C.: Center for Global 
Social Justice and Civilisational Crisis | 62

Development). Consulta: 21 de junio 2017. http://www.cgdev.org/content/publications/detail/1425089».

Brand, Ulrich, y Miriam Lang, 2015. "Green Economy". En Philipp Pattberg y Fariborz Zelli, edit., Encyclopedia of Global Environmental Politics and Governance, 461-9. Cheltenham-Northampton: Edward Elgar.

Brand, Ulrich y Markus Wissen. 2013. "Crisis socioecológica y modo de vida imperial: Crisis y continuidad de las relaciones sociedad-Naturaleza en el capitalismo". En Miriam Lang y Alejandra Santillana, comp., Más allá del capitalismo/colonialismo del siglo XXI, 445-70. Quito: Fundación Rosa Luxemburgo / Grupo Permanente de Trabajo sobre Alternativas al Desarrollo / AbyaYala.

-----. 2017. Imperiale Lebensweise. Zur Ausbeutung von Mensch und Natur in Zeiten des globalen Kapitalismus. Munich: Oekom Verlag.

Caffentzis, George, y Silvia Federici. 2015. "Comunes contra y más allá del capitalismo". El Apantle: Revista de estudios comunitarios, No 1: 53-71.

Cameron, Maxwell. 2009. "Latin America’s Left Turns: Beyond Good and Bad". Third World Quarterly 30, No. 2: 331-47.

CEPAL. 2012. Panorama social de América Latina. Santiago: Naciones Unidas / CEPAL.

-----. 2013. Los bonos en la mira: Aportes y carga para las mujeres. Santiago: Naciones Unidas / CEPAL.

Cielo, Cristina, y Cristina Vega. 2015. "Reproducción, mujeres y comunes: Leer a Silvia Federici desde el Ecuador actual". Nueva Sociedad, No. 256 (marzo-abril): $132-44$.

Cielo, Cristina, Lissett Coba, Ivette Vallejo. 2016. "Women, Nature and Development in Sites of Ecuador's Petroleum Circuit". Economic Anthropology, No. 3: 119-32. 
De Sousa Santos, Boaventura. 2002. Towards a New Legal Common Sense. Londres: Butterworth.

-----. 2009. Una epistemología del Sur. México: CLACSO y Siglo XXI.

-----. 2010. Descolonizar el saber, reinventar el poder. Montevideo: Trilce.

-----. 2011a. "Introducción: Las epistemologías del Sur”. En Alvise Vianello y Bet Mañé, coord., Formas otras: Saber, narrar, nombrar, hacer. IV Training Seminar de Jóvenes Investigadores en Dinámicas Interculturales, 9-22. Barcelona: Centro de Documentación Internacional de Barcelona (CIDOB). Consulta: 7 de junio 2017. http://www.boaventuradesousasantos.pt/media/INTRODUCCION_BSS.pdf).

-----. 2011b. "Epistemologías del Sur: Utopía y praxis latinoamericana”. Revista Internacional de Filosofía Iberoamericana y Teoría Social 16, No. 54: 17-39.

Echeverría, Bolívar. 2008. "La crisis civilizatoria”. Ponencia, Foro Crisis Económica y Crisis Civilizatoria, Instituto de Estudios Ecológicos del Tercer Mundo y FLACSOE, Quito, 17 de diciembre.

Escobar, Arturo. 2005. "El "postdesarrollo" como concepto y práctica social”. En Daniel Mato

(coord.), Políticas de economía, ambiente y sociedad en tiempos de globalización. Caracas: Facultad de Ciencias Económicas y Sociales, Universidad Central de Venezuela, pp. 17-31.

Escobar, Arturo. 2007. La invención del Tercer Mundo: Construcción y deconstrucción del desarrollo. Caracas: El Perro y la Rana.

-----. 2012. "Cultura y diferencia: La ontología política del campo de cultura y desarrollo". Wale'Keru: Revista de investigación en cultura y desarrollo, No. 2: Consulta: 3 de julio de 2017. http://biblioteca.hegoa.ehu.es/system/ebooks/19420/original/Cultura_y_diferencia .pdf?1366975231.

Esteva, Gustavo, Salvatore Babones y Philipp Babcicky. 2013. The Future of Development: A Radical Manifesto. Bristol: Policy Press. 
Farah, Ivonne, y Luciano Vasapollo. 2011. Vivir bien: ¿Paradigma no capitalista? La Paz: Universidad Mayor de San Andrés-Posgrado en Ciencias del Desarrollo.

Federici, Silvia . 2015. Calibán y la bruja: Mujeres, cuerpo y acumulación originaria. Buenos Aires: Tinta Limón.

Francisco, papa. 2015. "Carta encíclica Laudato Si sobre el cuidado de la casa común”. Consulta: 13 de septiembre de 2017. http://w2.vatican.va/content/dam/francesco/pdf/encyclicals/documents/papafrancesco_20150524_enciclica-laudato-si_sp.pdf.

Gago, Verónica, y Diego Sztulwark. 2016. "La temporalidad de la lucha social en el fin de ciclo eprogresista en América Latina". Consulta: 17 de enero de 2017. http://www.euronomade.info/?p=7862).

Gills, Barry K. 2010. "Going South: Capitalist crisis, Systemic crisis, Civilisational crisis”. Third World Quarterly 31, No. 2: 169-84.

Grugel, Jean, y Pia Riggirozzi. 2012. "Post-neoliberalism in Latin America: Rebuilding and Reclaiming the State after Crisis". Development and Change, No. 43: 1-21. Consulta: 21 de junio de 2017. http://onlinelibrary.wiley.com/doi/10.1111/j.1467-7660.2011.01746.x/full».

Gudynas, Eduardo. 2011c. "Desarrollo, derechos de la Naturaleza y buen vivir después de Montecristi”. En Gabriela Weber, edit., Debates sobre cooperación y modelos de desarrollo: Perspectivas desde la sociedad civil en el Ecuador, 83-102. Quito: Centro de Investigaciones Ciudad / Observatorio de la Cooperación al Desarrollo.

-----. 2015a. Extractivismos: Ecología, economía y política de un modo de entender el desarrollo y la naturaleza. Cochabamba: Centro de Documentación e Información Bolivia / Centro Latino Americano de Ecología Social.

Guillén, Alejandro. 2016. "Exploración de indicadores para la medición operativa del concepto del Buen Vivir”. Cuenca: PYDLOS, Universidad de Cuenca. 
Haug, Frigga. 2013. "División sexual del trabajo, economía del tiempo y buen vivir". En Miriam Lang y Alejandra Santillana, comp., Alternativas al capitalismo/colonialismo del siglo XXI: 417-30. Quito: Fundación Rosa Luxemburgo / Grupo Permanente de Trabajo sobre Alternativas al Desarrollo / AbyaYala.

Helfrich, Silke. 2016. "Configurations of State Power and the Commons: Transcending a Problematic Relationship”. Comunicación no publicada, elaborada para el Taller "Deep Dive Workshop" en Lehnin cerca de Potsdam 28 de febrero-2 de marzo.

Hoetmer, Raphael. 2011. "Podremos sobrevivir a la crisis terminal del capitalismo?". Entrevista con Edgardo Lander. En Gina Vargas, Mar Daza y Raphael Hoetmer, edit., Crisis y movimientos sociales en nuestra América: Cuerpos, territorios e imaginarios en disputa. Lima: Programa Democracia y Transformación Global.

Illich, Ivan. 1974. "Pobreza planificada”. Diálogo social, No. 37: 7-15.

-----. $1990 . \quad$ Needs. Manuscrito inconcluso.
‘http://www.surrenderworks.com/ivanillich/1990_needs.pdf. Consulta: 6 de junio de 2017.

-----. 2008. "Development as Planned Poverty". En Majid Rahnema y Victoria Bawtree, coord., The Post-Development Reader, 94-101. Nueva York-Londres: Zed Books.

Kapoor, Ilan. 2008. "The Culture of Development Policy: Basic Needs, Structural Adjustment, Good Governance, and Human Rights". En The Postcolonial Politics of Development, 19-38. Londres-Nueva York: Routledge.

Lander, Edgardo. 2007. "Marxismo, eurocentrismo, colonialismo”. En Atilio Borón, Javier Amadeo y Sabrina González, comp., La teoría marxista hoy: Problemas y perspectivas, 209-43. Buenos Aires: Consejo Latinoamericano de Ciencias Sociales (CLACSO).

-----. 2008. Contribución a la crítica del marxismo realmente existente: Verdad, ciencia y tecnología. Caracas: El Perro y la Rana. 
-----. 2009. "Estamos viviendo una profunda crisis civilizatoria”. Aportes: Revista de la Facultad de Economía XIV, No. 41: 197-200.

-----. 2013. "Crisis civilizatoria, límites del planeta, asaltos a la democracia y pueblos en resistencia”. En Miriam Lang y Alejandra Santillana, comp., Alternativas al capitalismo/colonialismo del siglo XXI, 27-62. Quito: Fundación Rosa Luxemburgo / Grupo Permanente de Trabajo sobre Alternativas al Desarrollo / Abya-Yala.

-----. 2016. "The Challenges of Emancipatory Politics Today: The Experience of the Bolivarian Revolution". Ponencia, Seminario Crisis of Politics and the Political Crisis, Alternative Information \& Development Centre, Ciudad del Cabo, 2-3 de diciembre.

Lang, Miriam. 2011. "Crisis civilizatoria y desafíos para las izquierdas". En Miriam Lang y Dunia Mokrani, comp., Más allá del desarrollo, 7-20. Quito: Fundación Rosa Luxemburgo / Grupo Permanente de Trabajo sobre Alternativas al Desarrollo / AbyaYala.

Lang, Miriam y Dunia Mokrani, comp., Más allá del desarrollo, 7-20. Quito: Fundación Rosa Luxemburgo / Grupo Permanente de Trabajo sobre Alternativas al Desarrollo / Abya-Yala.

Lang, Miriam. 2017. “¿Erradicar la pobreza o empobrecer las alternativas? Las políticas ecuatorianas de "erradicación de la pobreza" de la Revolución Ciudadana a la luz de la crisis civilizatoria”. Quito: Universidad Andina Simón Bolívar y Abya Yala.

Lavinas, Lena. 2014. "La asistencia social en el Siglo XXI". New Left Review, No. 84, segunda época (enero-febrero): 7-48.

León, Mauricio. 2015. "Del discurso a la medición. Propuesta metodológica para medir el Buen Vivir en Ecuador. Quito: Instituto Nacional de Estadísticas y Censos. Lustig, Nora, Carola Pessino y John Scott. 2013. "The Impact of Taxes and Social Spending on Inequality and Poverty in Argentina, Bolivia, Brazil, Mexico, Peru and Uruguay: An Overview”. CEQ Working Paper, No. 13 (Nueva Orleans: Tulane University-Center for Inter-American Policy and Research). Consulta: 21 de junio 
de

2017.

http://www.commitmentoequity.org/publications_files/CEQWPNo13\%20Lustig \%20et\%20al.\%20Overview\%20Arg,Bol,Bra,Mex,Per,Ury\%20April\%202013.pdf .

Meadows, Donella, Dennis Meadows, Jorgen Randers y William Behrens. 1972. The Limits to Growth: A Report for the Club of Rome on the Predicaments of Mankind. Washington DC: Potomac Associates.

Meschkat, Klaus. 2010. "La Tercera Internacional y América Latina”. En Miriam Lang y Alejandra Santillana, comp., Democracia, participación y socialismo: Bolivia, Ecuador, Venezuela, 44-58. Quito: Fundación Rosa Luxemburgo.

-----. 2015. "Los gobiernos progresistas y las consecuencias políticas del neoextractivismo". En Miriam Lang, Belén Cevallos y Claudia López, edit., ¿Cómo transformar?: Instituciones y cambio social en América Latina y Europa, 77-92. Quito: Fundación Rosa Luxemburgo / Grupo Permanente de Trabajo sobre Alternativas al Desarrollo / Abya-Yala.

Mies, Maria. 1998. "Decolonizing the Iceberg Economy: New Feminist Concepts for a Sustainable Society". En Linda Christiansen-Ruffman, edit., The Global Feminist Enlightenment: Women and Social Knowledge, 75-90. Madrid: International Sociological Association.

Moreno, Alejandro. 2000. "Superar la exclusión, conquistar la equidad. Reformas, políticas y capacidades en el ámbito social”. En Edgardo Lander, coord., La colonialidad del saber, eurocentrismo y ciencias sociales: Perspectivas latinoamericanas, 163-76. Buenos Aires: CLACSO.

Moreno, Camila, Daniel Speich y Lili Fuhr. 2015. "Carbon Metrics: Global Abstractions and Ecological Epistemicide". Publication Series Ecology, No. 42. Heinrich Böll Stiftung. Consulta: 20 de julio 2017. 〈https://www.boell.de/sites/default/files/20161108_carbon_metrics_2._auflage.pdf. N’Dione, Emmanuel. 1994. Réinventer le présent: Quelches jalons pour l'action. Dakar: Enda Graf Sahel. 
Social Justice and Civilisational Crisis | 68

-----. 2001. "La réciprocité: Une alternative au libre échange". L'écologiste, No. 6 : 46-8. Consulta: 5 de julio de 2017. http://www.museum.agropolis.fr/pages/savoirs/echange_nord_sud/n_dione_ecolog iste06.pdf.

N'Dione, Emmanuel, Philippe de Leener, Jean-Pierre Perier, Mamadou Ndiaye and Pierre Jacolin. 1997. "Reinventing the present: the Chodak experience in Senegal". En Majid Rahnema y Victoria Bawtree. The Post-development Reader. LondresNueva Jersey: Zed Books.

Nandy, Ashis. 2002. The Beautiful, Expanding Future of Poverty: Popular Economics as a Psychological Defense. Malden-Oxford: International Studies Association / Blackwell. Consulta: 6 de junio de 2017. ‘http://aud.ac.in/upload/The_Beautiful_Expanding_Future_of_Poverty.pdf.

Ornelas, Raúl, coord. 2013. Crisis civilizatoria y superación del capitalismo. CDMX: UNAM.

OXFAM. 2017. "Just 8 Men Own Same Wealth as Half the World". Consulta: 17 de enero de 2017. https://www.oxfam.org/en/pressroom/pressreleases/2017-0116/just-8-men-own-same-wealth-half-world.

Pérez-Orozco, Amaia. 2014. Subversión feminista de la economía: Aportes para un debate sobre el conflicto capital-vida. Madrid: Traficantes de Sueños.

PNUD, Programa de las Naciones Unidas para el Desarrollo. 2014. Informe sobre Desarrollo Humano 2014. Sostener el Progreso Humano: Reducir vulnerabilidades y construir resiliencia. Nueva York: PNUD. Consulta: 01 de agosto de 2017. http://www.undp.org/content/dam/undp/library/corporate/HDR/2014HDR/HD R-2014-Spanish.pdf.

-----. 2015. Objetivos de Desarrollo del Milenio. Informe 2015. Consulta: 13 de septiembre de 2017. http://www.co.undp.org/content/dam/colombia/docs/ODM/undp-coodsinformedoc-2015.pdf? 
Prada Alcoreza, Raúl. 2013. "Potencia, existencia y plenitud: El camino de la guerra y el camino de la sabiduría. Reflexiones en torno al sumak kawsay/suma qamaña”. Rebelión. Consulta: 28 de junio de 2017. 〈http://www.rebelion.org/docs/178426.pdf).

Rockström, Johan, Will Steffen, Kevin Noone, Åsa Persson, F. Stuart III Chapin, Eric Lambin, Timothy M. Lenton, Marten Scheffer, Carl Folke, Hans Joachim Schellnhuber, Björn Nykvist, Cynthia A. de Wit, Terry Hughes, Sander van der Leeuw, Henning Rodhe, Sverker Sörlin, Peter K. Snyder, Robert Costanza, Uno Svedin, Malin Falkenmark, Louise Karlberg, Robert W. Corell, Victoria J. Fabry, James Hansen, Brian Walker, Diana Liverman, Katherine Richardson, Paul Crutzen, y Jonathan Foley. 2009. "Planetary Boundaries: Exploring the Safe Operating Space for Humanity”. Ecology and Society 14, No. 2, Art. 32: s. p. Consulta: 2 de agosto de 2017. https://www.ecologyandsociety.org/vol14/.../ES-2009-3180.pdf».

Rodríguez, Mario. 2013. "Resignificando la ciudad colonial y extractivista". En Miriam Lang y Alejandra Santillana, comp., Alternativas al capitalismo/colonialismo del siglo XXI, 225-58. Quito: Fundación Rosa Luxemburgo / Grupo Permanente de Trabajo sobre Alternativas al Desarrollo / Abya-Yala.

Rosa, Hartmut. 2013a. Beschleunigung und Entfremdung. Frankfort: Suhrkamp.

-----. 2013b. Social Acceleration: A New Theory of Modernity. Nueva York: Columbia University Press.

Salleh, Ariel. 1997. Ecofeminism as Politics: Nature, Marx and the Postmodern. Londres-Nueva York: Zed Books.

Sangmeister, Hartmut. 2008. "Die «Bolivarische Revolution`: Hoffnung für die Armen Lateinamerikas?”. GIGA Focus, No. 3 (Hamburgo: German Institute of Global and Area Studies): Consulta: 20 de julio de 2017. ‘http://www.ssoar.info/ssoar/bitstream/handle/document/27649/ssoar-2008sangmeister-die_bolivarische_revolution_hoffnung_fur.pdf?sequence $=1$. .

Shiva, Vandana. 1991. The Violence of the Green Revolution: Third World Agriculture, Ecology and Politics. Londres-Nueva Jersey: Zed Books. 
-----. 2004. "La mirada del ecofeminismo (tres textos)". Polis: Revista latinoamericana, No. 9. Consulta: 13 de enero de 2017. http://polis.revues.org/7270).

Speich, Daniel. 2011. "The Use of Global Abstractions: national income accounting in the period of imperial decline". Journal of Global History, No. 6: 7-28.

Svampa, Maristella. 2013. “Consenso de los Commodities` y lenguajes de valoración en América Latina”. Nueva Sociedad, No. 244 (marzo-abril): 30-46.

Viteri Gualinga, Carlos. 2002. "Visión indígena del desarrollo en la Amazonía”. Polis: Revista latinoamericana, No. 3: 1-6. Consulta: 23 de junio de 2017. http://polis.revues.org/7678».

Wahl, Achim. 2016. "Zur Lage der linken Regierungen und Parteien in Lateinamerika: Zur Entwicklung in Lateinamerika in den Jahren 2015/2016". Berlín: Rosa Luxemburg Stiftung. Consulta: 21 de junio de 2017. https://www.rosalux.de/fileadmin/rls_uploads/pdfs/sonst_publikationen/OnlinePubl_Lage-linke-Regierungen_Parteien-LA.pdf).

Walsh, Catherine. 2009a. Interculturalidad, Estado y sociedad: Luchas (de)coloniales de nuestra época. Quito: UASB-E / Abya-Yala.

Welzer, Harald. 2012. Mental Infrastructures: How Growth Entered the World and Our Souls. Berlín: Heinrich Böll Stiftung. Consulta: 17 de enero de 2017. https://www.boell.de/sites/default/files/endf_mental_infrastructures.pdf.

-----. 2013. Selbst Denken. Eine Anleitung zum Widerstand. Francfort: Fischer Taschenbuch Verlag.

Wissen, Markus. 2013. "Auf dem Weg in einen grünen Kapitalismus? Die ökologische Modernisierung der imperialen Lebensweise". Berlín: Fundación Rosa Luxemburg. Consulta: 2 de agosto de 2017.

http://ifg.rosalux.de/files/2014/05/Imperiale-Lebensweise_2014-05-07.pdf. 